\title{
Biochar for Enhancing Agricultural Sustainability under Climate Change
}

\author{
Rohitash Bajiya ${ }^{1}$, Hansa Lakhran², Sandeep Kumar ${ }^{3}$ and Seema ${ }^{4 *}$ \\ ${ }^{1}$ Department of Agronomy, Indian Agricultural Research Institute, Pusa Campus, \\ New Delhi - 110012, India \\ ${ }^{2}$ S. K. N. Agriculture University, Jobner, Jaipur, Rajasthan-303329, India \\ ${ }^{3}$ Choudhary Charan Singh Haryana Agricultural University, Hisar-125004, India \\ ${ }^{4}$ Department of Soil Science and Agricultural Chemistry, Institute of Agricultural Sciences, \\ Banaras Hindu University, Varanasi - 221005, India \\ *Corresponding author
}

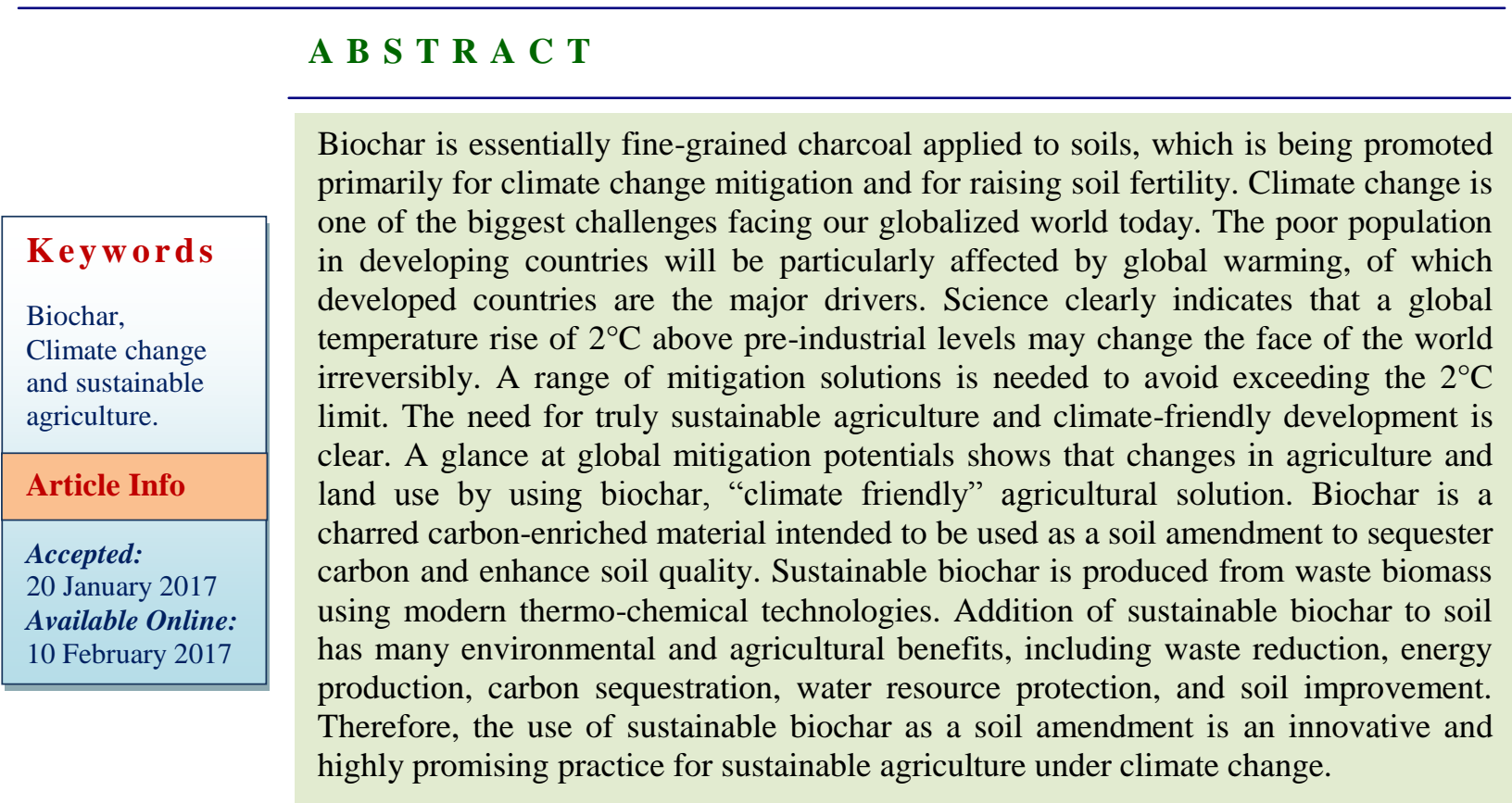

\section{Introduction}

The term 'biochar' refers to black carbon formed by the pyrolysis of biomass i.e. by heating biomass in an oxygen-free or low oxygen environment such that it does not (or only partially) combusts. Traditional charcoal is one example of biochar produced from wood. The term 'biochar' is much broader than this however, encompassing black carbon produced from any biomass feedstock.
The use of biochar as a soil additive has been proposed as a means to simultaneously mitigate anthropogenic climate change whilst improving agricultural soil fertility. This paper provides a review of what is known about both of these claims and also about the wider environmental implications of the adoption of this process. The intention of this review is not just to summarize current 
knowledge of the subject, but also to identify gaps in knowledge that require further research.

Climate change is now widely recognized as a serious threat to both human society and natural ecosystems. The IPCC (Forster et al., 2007) stated that "since 1750 , it is extremely likely that humans have exerted a substantial warming influence on climate", where the term 'extremely likely' is defined to mean "with a confidence limit of $95 \%$ or greater". If this anthropogenic warming trend continues, we may face impacts that are "abrupt and irreversible" (IPCC, 2007). And Stern (2007) concluded that the economic impact of climate change under a 'business as usual' scenario would exceed the combined cost of the great depression and the two World Wars.

In a study of the long-term (500 years) implications of various greenhouse gas emission scenarios, Weaver et al., (2007) concluded that a minimum of $60 \%$ global reduction in emissions by 2050 will be needed to keep temperature rises this century below the $2^{\circ} \mathrm{C}$ threshold "that some have argued represents an upper bound on manageable climate warming". However, Weaver et al., (2007) also found that even if emissions are stabilized at $90 \%$ below current levels by 2050 , the $2.0^{\circ} \mathrm{C}$ temperature rise will still be exceeded eventually. They argue therefore that "if a $2.0^{\circ} \mathrm{C}$ warming is to be avoided, direct $\mathrm{CO}_{2}$ capture from the air, together with subsequent sequestration, would eventually have to be introduced in addition to sustained 90\% global carbon emissions reductions by 2050".

But how this direct capture from the air and sequestration of $\mathrm{CO}_{2}$ might be achieved? Most of the proposed methods of carbon capture and storage (CCS) are aimed at capturing $\mathrm{CO}_{2}$ directly from exhaust emissions before they have entered the atmosphere (IPCC, 2005). As such, they can be considered as strategies to reduce emissions rather than to remove $\mathrm{CO}_{2}$ from the atmosphere. There is one exception to this where CCS is used to capture and sequester $\mathrm{CO}_{2}$ emissions from biomass combustion. In this case, the complete system, including photosynthesis to provide the biomass, becomes a net carbon sink. At present, few other plausible methods for the large scale removal of $\mathrm{CO}_{2}$ from the atmosphere are known: one possibility is to increase the size of the earth's biomass carbon pool (for example by reforestation, reduced tillage or other land-use changes) and a second is the production and sequestration of biochar.

In its third assessment report, The IPCC (2001) estimated that the terrestrial biosphere could mitigate between 10 and $20 \%$ of the world's fossil fuel emissions by 2050 . However, in the recent fourth assessment report, Barker et al., (2007) focus on the host of uncertainties in how terrestrial ecosystems will respond to climate change, leading to an uncertainty in whether it might become a net carbon emitter or sink. Smith et al., (2007) suggest four other possible mechanisms that may account for the loss in agricultural soil carbon: reduced spreading of animal manure, increased removal of agricultural residues, deeper ploughing, and possible legacy effects from pre 1978changes in land use. Smith et al., (2007) also suggest some possible mechanisms to account for carbon losses from organic soils (such as peat bogs) such as lowering water table, recovery from acidification, enhanced atmospheric nitrogen deposition, or increased use of biochar.

It would appear, then, that removal of excess $\mathrm{CO}_{2}$ from the atmosphere will form an important part of an overall climate change mitigation strategy alongside a portfolio of measures to reduce greenhouse gas emissions. Furthermore, it would appear that strategies 
such as enhanced net primary production of the terrestrial biosphere (for example by afforestation) and enhanced carbon deposition in oceans by fertilization may not alone be up to the task of wholesale removal of atmospheric carbon. So, let us now turn our attention to another strategy by which removal of atmospheric $\mathrm{CO}_{2}$ might be achieved - the production and sequestration of biochar.

\section{What is biochar?}

Biochar is a carbon rich charcoal-like substance created by thermal decomposition biomass (organic matter) in low oxygen conditions at relatively low temperatures $\left(<700^{\circ} \mathrm{C}\right)$, a process known as pyrolysis. Almost half of dry biomass weight is pure carbon. If biomass is left to decompose in air, almost all of the carbon is lost into the atmosphere within a few years. During pyrolysis, around $50 \%$ of biomass carbon is converted into biochar. Of the other $50 \%$, around two thirds can be released as useful energy. Thus $1 \mathrm{Mt}$ of dry biomass sequesters (locks away) $0.3 \mathrm{Mt}$ of carbon, equivalent to 1.2 $\mathrm{Mt} \mathrm{CO}_{2}$.

\section{Biochar for sustainable agriculture}

The most common definition of sustainability is when society and systems use, consume or employ resources at a rate and in a way which ensures that future generations (of all species) will be able to benefit equally from those same resources. The Bruntland Commission is credited with coining a definition of sustainable development as "meeting present needs without compromising the ability of future generations to meet their needs". Sustainability concerns cover the carrying capacity and resilience of environmental, social and economic systems and to the interrelationships within the whole. Sustainable agriculture is a way of raising food that is healthy for consumers and animals without causing damage to ecosystem health. Low nutrient content and accelerated mineralization of soil organic matter (SOM) are the two major constraints currently encountered in sustainable agriculture (Renner, 2007). Nutrients are retained in soil and remain available to crops mainly by adsorption to minerals and soil organic matter. Usually, the addition of organic matter such as compost and manure into soil can help retain nutrients. Biochar is considered much more effective than other organic matter in retaining and making nutrients available to plants. Its surface area and complex pore structure are hospitable to bacteria and fungi that plants need to absorb nutrients from the soil. Moreover, biochar is a more stable nutrient source than compost and manure (Chan et al., 2007).

The modality of biochar in its ability to act as an effective soil amendment is similar to the traditional "slash-and-burn" fertilization method, where farmers remove the vegetation and release a pulse of nutrients to fertilize the soil. But the "slash-and-burn" practice has an unfavorable environmental reputation because it is associated with deforestation and air pollution. In contrast, biochar production under a controlled system may provide a higher yield and have fewer detrimental effects on the environment. These characteristics make biochar an exceptional soil amendment for use in sustainable agriculture under climate change, (Lehmann and Joseph, 2008; Verhejien et al., 2010).

Several greenhouse and field studies have been conducted to examine the effect of biochar on crop yields (Glaser et al., 2002; Yamato, et al., 2006; Chan et al., 2007 and 2008). Most studies showed that biochar addition increased crop yields. For example, a plot trial where soil was amended with a green waste-derived biochar, showed benefits that included increased crop yield and 
improved soil quality (Chan et al., 2007). Field experiments have also reported substantial crop yield increase in response to soil biochar application (Glaser et al., 2002; Yamato et al., 2006). Most of these experiments, however, were conducted in the Tropics using biochar produced in local earthen kilns and applied to soils with low organic matter content (Laird, 2008). The varying effects on crop yield appear to depend on such factors as biochar quality, biochar quantities added, soil type, and crop tested. However, much more research is needed to understand the interactions between biochar, soil, climates, and crops.

\section{Implications of biochar use}

\section{Economic implications}

The economic cost of implementing biochar production and use is important not just because it determines how readily and rapidly we might deploy the technology, but also because it must compete for finance and resources with other technologies that may likewise be aimed at climate change abatement and soil quality improvement (Woolf, 2008). Using the highest carbon content of the wood-based biochar (i.e. 80\%) and the $\mathrm{CO}_{2}$ offset price range, the approximate value of biochar $\mathrm{C}$ sequestration is \$ 2.93-\$90.83 per metric ton of biochar. The potential economic returns to farmers if they utilize biochar as a substitute for agricultural lime under three price scenarios: (a) \$114.05 per metric ton based on the energy content of a wood-based biochar; (b) $\$ 87$ per metric ton; and (c) $\$ 350.74$ per metric ton. The first value represents the opportunity cost of the foregone use of biochar as energy source.

Transportation distance has significant effects on costs, whereas ramifications for $\mathrm{GHG}$ emissions are low. Even transporting the feedstock and biochar each $200 \mathrm{~km}$, the net
$\mathrm{CO}_{2}$ emission reductions decrease by only $5 \%$ of the baseline $(15 \mathrm{~km})$. At $1000 \mathrm{~km}$, the net GHG emission reductions decrease by $28 \%$ to $-626 \mathrm{~kg} \mathrm{CO}_{2}$. The net energy is more sensitive than the GHG emissions to the transport distance. At $200 \mathrm{~km}$ the net energy decreases by $15 \%$, and at $1000 \mathrm{~km}$, the net energy decreases by $79 \%$ to 863 MJ. Costs are the most sensitive to transportation distance, where costs increase by $\$ 0.80$ to 1 for every $10 \mathrm{~km}$. Therefore, biochar systems are most economically viable as distributed systems with low transportation requirements (Roberts et al., 2010).

\section{Environmental Implications}

The temperature rise is predominantly because of increases in atmospheric greenhouse gas emissions, dominated by carbon dioxide $\left(\mathrm{CO}_{2}\right)$. Eleven of the last 12 years rank among the 12 warmest years in the instrumental record of global surface temperature (since 1850). The 100-year linear trend $(1906-2005)$ is $0.74^{\circ} \mathrm{C}(0.56-0.92)$. Globally, soils contain about $1500 \mathrm{Pg}(1 \mathrm{Pg}$ $=1 \mathrm{Gt}$ ) of organic carbon (Batjes, 1996), about three times the amount of carbon in vegetation and twice the amount in the atmosphere (IPCC WGI, 2001). Smith et al., (2008) suggested that technologies, which promote soil carbon sequestration, will also help to mitigate climate change itself (by reducing atmospheric $\mathrm{CO}_{2}$ concentrations) and are cost competitive with mitigation options available in other sectors.

Sohi et al., (2009) raised certain pertinent questions regarding biochar application to the soil. According to them, in short-term experiments ranging from months to a few years, biochar addition seems to generally enhance plant growth and soil nutrient status and decrease nitrous oxide $\left(\mathrm{N}_{2} \mathrm{O}\right)$ emissions. Surprisingly, little is yet published concerning how these benefits occur, or particularly why 
the effects are quantitatively so variable according to crop, soil and application rate. Therefore, despite the recent interest in biochar as soil amendment for improving soil quality and soil carbon sequestration, implications of long-term biochar application on environmental conditions need to be assessed (Jha et al., 2010).

\section{Biochar to mitigate climate change}

Adding biochar to soils has been described as a means of sequestering atmospheric carbondioxide $\left(\mathrm{CO}_{2}\right)$ (Lehmann et al., 2006). For this to represent true sequestration, two requirements have to be met. First, plants have to be grown at the same rate as they are being charred because the actual step from atmospheric $\mathrm{CO}_{2}$ to an organic $\mathrm{C}$ form is delivered by photosynthesis in plants. Yet, plant biomass that is formed on an annual basis typically decomposes rapidly. This decomposition releases the $\mathrm{CO}_{2}$ that was fixed by the plants back to the atmosphere. In contrast, transforming this biomass into biochar that decomposes much more slowly diverts $\mathrm{C}$ from the rapid biological cycle into a much slower biochar cycle (Lehmann, 2007b). Second, the biochar needs to be truly more stable than the biomass from which it was formed.

Several approaches have been taken to provide first estimates of the large-scale potential of biochar sequestration to reduce atmospheric $\mathrm{CO}_{2}$ (Lehmann et al., 2006; Lehmann, 2007b; Laird, 2008), which will need to be vetted against economic and ecological constraints and extended to include a full emission balance. Such emission balances require a comparison to a baseline scenario, showing what emissions have been reduced by changing to a system that utilizes biochar sequestration. Until more detailed studies based on concrete locations reach the information density required to extrapolate to the global scale, a simple comparison between global $C$ fluxes may need to suffice to demonstrate the potential of biochar sequestration. Almost four times more organic C is stored in the Earth's soils than in atmospheric $\mathrm{CO}_{2}$. And every 14 years, the entire atmospheric $\mathrm{CO}_{2}$ has cycled once through the biosphere. Furthermore, the annual uptake of $\mathrm{CO}_{2}$ by plants is eight times greater than today's anthropogenic $\mathrm{CO}_{2}$ emissions. This means that large amounts of $\mathrm{CO}_{2}$ are cycling between atmosphere and plants on an annual basis and most of the world's organic C is already stored in soil. Diverting only a small proportion of this large amount of cycling $\mathrm{C}$ into a biochar cycle would make a large difference to atmospheric $\mathrm{CO}_{2}$ concentrations, but very little difference to the global soil $\mathrm{C}$ storage. Diverting merely 1 per cent of annual net plant uptake into biochar would mitigate almost 10 per cent of current anthropogenic $\mathrm{C}$ emissions.

\section{Potentials of Biochar use in India}

With a production of 93.9 million tons (Mt) of wheat, 104.6 Mt of rice, 21.6 Mt of maize, 20.7 Mt of millets, 357.7 Mt of sugarcane, 8.1 Mt of fiber crops (jute, mesta, cotton), 17.2 Mt of pulses and $30.0 \mathrm{Mt}$ of oilseeds crops, in the year 2011-12 (MOA, 2012), it is but natural that a huge volume of crop residues are produced both on-farm and off farm. It is estimated that approximately 500-550 Mt of crop residues are produced per year in the country (IARI, 2012). Efficient and sustainable disposal of organic waste remains a key issue in rural farm areas and in urban societies. Most wastes are either burnt or end up in landfill, which degrade the environment and also produce large amounts of GHGs. The production of biochar from farm wastes and their application in farm soils offer multiple environmental and financial benefits. Biochar use has a very promising potential for the development of sustainable agricultural 
systems in India, and also for global climate change mitigation. There is significant availability of non-feed biomass resources in the country as potential feedstock for biochar production. The current availability of biomass in India (2010-2011) is estimated at about 500 million metric tons/year. Studies sponsored by the Ministry ofNewand Renewable Energy, Govt. of India have estimated surplus biomass availability at about 120-150 million metric tons/annum. Biochar having high $\mathrm{pH}$ value can be a good remedy for acid soil amelioration. North-East India has the potentiality of producing 37 million tons of agricultural waste biomass. If only $1 \%$ of this biomass is converted to biochar, about 74 thousand tons of carbon can be sequestered annually. Out of this, if $1 \%$ of the process of producing biochar is carried out through modern equipment, about 1300 and 900 tons of bio-oil and biogas can be produced, respectively which is equivalent to 31 terra joule of energy.

Moreover, in rural India, women cook their food with biomass (mostly wood and charcoal) in highly polluting stoves, which represent a number of problems including deforestation, lots of time spent on wood collection and on cooking, back pains and other life-threatening risks. Furthermore, charcoal is inefficiently produced in the earthmound kiln releasing a considerable amount of methane emissions. Therefore, the establishment of the commercialization chain of highly-efficient biochar-making cook stoves, diffusion of improved small-scale kilns, pyrolysis of agricultural residues that are burnt otherwise, offer an opportunity to enhance the living conditions of rural families, counteract deforestation, protect biodiversity, increase crop production, improve agricultural waste management and remove carbon from the atmosphere as a carbon-negative strategy to fight global warming (Anonymous, 2012).

\section{Constraints of biochar use in India}

One factor determining how much biochar may be produced is the existence of competing demands for biomass feedstock. Production of biochar is, of course, not the only use that can be made of biomass. Numerous other applications for various types of biomass have been used in the past, are in current demand, and may become popular in the future. The crop residues and other biomass are used for animal feeding, soil mulching, bio-manure making, thatching for rural homes and fuel for domestic and industrial use. Once environmental costs of carbon-based greenhouse gas emissions have been suitably internalized, we can expect market forces and the price mechanism to be the dominant factor in apportioning use of biomass resources between competing demands (Woolf, 2008). Other constraints on biochar production methods arise because emissions of $\mathrm{CH}_{4}, \mathrm{~N}_{2} \mathrm{O}$, soot or volatile organic compounds combined with low biochar yields (for example, from traditional charcoal kilns or smoldering slash piles) may negate some or all of the carbon-sequestration benefits, cause excessive carbon-payback times or be detrimental to health (Woolf et al., 2010). However, to promote the application of biochar as a soil amendment, and also as a climate change abatement option, research, development and demonstration on biochar production and application is very vital.

\section{References}

Anonymous, 2012. Good stoves and biochar community project. http://www. biocharindia.com/Home/good-stovesand-biochar-community-project accessed on 22 November, 2012.

Barker, T., I. Bashmakov, L. Bernstein, J. E. Bogner, P. R. Bosch, R. Dave, O. R. Davidson, B. S. Fisher, S. Gupta, K. 
Halsnæs, G.J. Heij, S. Kahn Ribeiro, S. Kobayashi, M. D. Levine, D. L. Martino,O. Masera, B. Metz, L. A. Meyer, G.-J. Nabuurs, A. Najam, N. Nakicenovic, H. -H. Rogner, J. Roy,J. Sathaye, R. Schock, P. Shukla, R. E. H. Sims, P. Smith, D. A. Tirpak, D. UrgeVorsatz, D. Zhou,2007: Technical Summary. In: Climate Change 2007: Mitigation. Contribution of Working Group IIIto the Fourth Assessment Report of the Intergovernmental Panel on Climate Change [B. Metz, O.R.Davidson, P. R. Bosch, R. Dave, L. A. Meyer (eds)], Cambridge University Press, Cambridge,United Kingdom and New York, NY, USA.

Batjes, N.H., 1996. Total carbon and nitrogen in the soils of the world. European Journal of Soil Science, 47: 151-163.

Chan, K. Y., Zwieten, L. V., Meszaros, I., Downie, A., Joseph, S., 2007. Agronomic values of greenwaste biochar as a soil amendment. Australian J. Soil Res. 45, 629-634.

Chan, K. Y., Zwieten, L. V., Meszaros, I., Downie, A., Joseph, S., 2008. Using poultry litter biochar as soil amendments. Australian J. Soil Res. 46, 437-444.

Forster, P., V. Ramaswamy, P. Artaxo, T. Berntsen, R. Betts, D.W. Fahey, J. Haywood, J. Lean, D.C.Lowe, G. Myhre, J. Nganga, R. Prinn, G. Raga, M. Schulz and R. Van Dorland, 2007: Changes in Atmospheric Constituents and in Radiative Forcing. In: Climate Change 2007: The Physical Science Basis. Contribution of Working Group I to the Fourth Assessment Report of the Intergovernmental Panel on Climate Change [Solomon, S., D. Qin, M. Manning, Z. Chen, M.Marquis, K.B. Averyt, M.Tignor and H.L. Miller (eds.)]. Cambridge University Press, Cambridge,United Kingdom and New York, NY, USA.
Glaser, B., Lehmann, J., Zech, W. 2002. Ameliorating physical and chemical properties of highly weathered soils in the tropics with charcoal-a review. Biol. Fertil. Soils 35, 219-230.

IARI, 2012. Crop residues management with conservation agriculture: Potential, constraints

and policy needs. Indian Agricultural Research Institute, New Delhi, 32 p.

IPCC, 2001. Climate change 2001: The scientific basis. Contribution of Working Group I to the Third Assessment Report of the Intergovernmental Panel on Climate Change (Houghton, J.T., Ding, Y., Griggs, D.J., Noguer, M., Vander Linden, P.J., Dai, X., Maskell, K. and Johnson, C.A. (Eds.)), Cambridge University Press, Cambridge and New York.

IPCC, 2005: IPCC Special Report on Carbon Dioxide Capture and Storage. Prepared by WorkingGroup III of the Intergovernmental Panel on Climate Change [Metz, B., O. Davidson, H. C. deConinck, M. Loos, and L. A. Meyer (eds.)]. Cambridge University Press, Cambridge, UnitedKingdom and New York, NY, USA.

IPCC, 2007. "Climate Change 2007: The Physical Science Basis. Summary for Policymakers", Contribution of Working Group I to the Fourth Assessment Report of the Intergovernmental Panel on Climate Change.

Jha, P., Biswas, A.K., Lakaria, B.L. and Subba Rao, A., 2010. Biochar in agriculture -prospects and related implications. Current Science, 99 (9): 1218-1225.

Laird,D.A. (2008) 'The charcoal vision:A win-win-win scenario for simultaneously producing bioenergy, permanently sequestering carbon, while improving soil and water quality', Agronomy Journal, vol 100, pp178-181 
Lehmann, J., Gaunt, J. and Rondon, M. (2006). 'Bio-char sequestration in terrestrial ecosystems - a review', Mitigation and Adaptation Strategies for Global Change, vol 11, pp 403-427.

Lehmann, J. (2007a) 'Bio-energy in the black', Frontiers in Ecology and the Environment, vol 5, pp381-387

Lehmann, J. (2007b) 'A handful of carbon', Nature, vol 447, pp143-144.

Lehmann, J., Joseph, S., Ed. 2008. Biochar for Environmental Management Science and Technology, Earthscan: Sterling, VA.

MoA, 2012. Ministry of Agriculture, Govt. of India, New Delhi. www.eands. dacnet.nic.in.

Renner, R., 2007. Rethinking biochar. Environ. Sci. Technol. 41, 5932-5933.

Roberts, K.G., Gloy, B.A., Joseph, S., Scott, N.R. and Lehmann, J. 2010. Life cycle assessment of biochar systems: estimating the energetic, economic, and climate change potential. Environmental Science \& Technology, 44(2): 827-833.

Smith, Pete, Stephen J. Chapman, W. Andy Scott, Helaina I. J. Black, Martin Wattenbach, RonnieMilne, et al., (2007), "Climate change cannot be entirely responsible for soil carbon loss observed inEngland and Wales, 1978-2003", Global Change Biology 13, no. 12 (December): 2605-2609.

Smith, P., Fang, C., Dawson, J.J.C. and Moncrieff, J.B. 2008. Impact of global warming on soil organic carbon. Advances in Agronomy, 97: 1-43.

Sohi, S., Lopez-Capel, E., Krull, E and Bol, R. 2009. Biochar's roles in soil and climatechange: A review of research needs. CSIRO Land and Water Science Report 05/09,p 64.

Stern (2007). http://www.hmtreasury. gov.uk/independent_reviews/stern_revie w_economics_climate_change/stern_revi ew_report.cfm

Verhejien,F., Jeddery, S., Bastos, A., van der Velde, C. M., Diafas, I., 2010. Biochar Application to Soils, JRC Scientific and Technical Reports: Institute for Environment and Sustainability, European Communities.

Weaver, A. J., K. Zickfeld, A. Montenegro, and M. Eby. 2007. Long term climate implications of 2050 emission reduction targets. Geophysical Research Letters 34, no. 19.

Woolf, D. 2008. Biochar as a soil amendment: A review of the environmental implications. (Accessed online

athttp://orgprints.org/13268/1/Biochar_as _a_soil_amendment_- a_review.pdf).

Woolf, D., Amonette, J.E., Street-Perrott, F.A., Lehmann, J and Joseph, S. 2010. Sustainable

biochar to mitigate global climate change. Nature Communications, 1: 1-9.

Yamato, M., Okimori., Y., Wibowo, I. F., Anshori, S., Ogawa, M., 2006. Effect of the application of charred bark of Acacia mangium on the yield of maize, cowpea and peanut, and soil chemical properties in South Sumatra, Indonesia. Soil Sic. Plant Nut. 52, 489-495.

\section{How to cite this article:}

Rohitash Bajiya, Hansa Lakhran, Sandeep Kumar and Seema. 2017. Biochar for Enhancing Agricultural Sustainability under Climate Change. Int.J.Curr.Microbiol.App.Sci. 6(2): 18761883. doi: http://dx.doi.org/10.20546/ijcmas.2017.602.212 